\title{
Effect of phytase supplementation of diets with different levels of phosphorus on performance and egg quality of laying hens in hot climatic conditions
}

\author{
M. Çabuk ${ }^{\# 1}$, M. Bozkurt ${ }^{2}$, F. Kırkpınar ${ }^{3}$ and H. Özkul ${ }^{3}$ \\ ${ }^{1}$ Department of Poultry Science, Akhisar Vocational School of Celal Bayar University, 45210, Manisa-Turkey \\ ${ }^{2}$ Poultry Research Institute, Erbeyli 09600, Aydın-Turkey \\ ${ }^{3}$ Department of Animal Science, Agricultural Faculty of Ege University, Bornova 35100, Izmir-Turkey
}

\begin{abstract}
Four hundred and eighty 54-week old Nick-Brown hens were assigned to four dietary treatments. Each treatment consisted of four replications of 10 cages (three hens per cage). The experimental diets were: $4.5 \mathrm{~g}$ available phosphorus (aP)/kg without phytase (control); $4.5 \mathrm{~g}$ aP/kg with phytase; $3.0 \mathrm{~g}$ aP/kg without phytase; $3.0 \mathrm{~g} \mathrm{aP} / \mathrm{kg}$ with phytase. Commercial microbial phytase, Natuphos ${ }^{\circledR}$, was added at 300 phytase unit (FTU) $/ \mathrm{kg}$ diet. Diets were isonitrogenous (16.5\% crude protein) and isoenergetic (11.5 MJ, ME/kg). Criteria evaluated included egg production, feed consumption, feed conversion, proportion of cracked/broken eggs, egg weight, eggshell weight, eggshell strength, eggshell thickness and body weight. Phytase supplementation to the control diet $(4.5 \mathrm{~g} \mathrm{aP} / \mathrm{kg})$ and the low $3.0 \mathrm{~g}$ aP/ $/ \mathrm{kg}$ diet significantly increased hen-day egg production from 75.49 to $77.96 \%$ and from 64.59 to $76.54 \%$, respectively. Average daily feed consumption was significantly different between treatments: Phytase supplementation to the control and the $3.0 \mathrm{~g} \mathrm{aP} / \mathrm{kg}$ diets increased daily feed consumption significantly from 101.31 to $103.43 \mathrm{~g} /$ day and from 95.24 to $101.69 \mathrm{~g} /$ day, respectively. There were no significant differences between the treatments in eggshell weight, eggshell thickness, eggshell strength and cracked/broken eggs. Phytase supplementation to the control $(4.5 \mathrm{~g} \mathrm{aP} / \mathrm{kg})$ and the $3.0 \mathrm{~g}$ aP $/ \mathrm{kg}$ diets increased egg weight significantly from 62.66 to $64.32 \mathrm{~g}$. and from 62.49 to $63.98 \mathrm{~g}$, respectively. The beneficial effects of phytase supplementation to laying hen diets were clearly evident under the high ambient temperatures pertaining to this study. Hens consuming the $3.0 \mathrm{~g}$ $\mathrm{aP} / \mathrm{kg}$ diet with phytase performed as well as hens fed the diet containing $4.5 \mathrm{~g}$ aP/ $/ \mathrm{kg}$ without phytase.
\end{abstract}

Keywords: Phytase, laying hen, available phosphorus, performance, ambient temperature

"Corresponding author. E-mail: metin.cabuk@deu.edu.tr

\section{Introduction}

Generally, maize and soyabean meal are the major feedstuffs in the diets of poultry. About two-thirds of the phosphorus of plant origin is present as phytic acid. Phosphorus (P) in phytic acid form is poorly available to monogastric animals, due to the lack of phytase in their digestive tracts. The low bioavailability of $\mathrm{P}$ in plant ingredients poses problems both economically and environmentally. After energy and protein, phosphorus is the most expensive component in a poultry diet. Environmentally, a large proportion of consumed $\mathrm{P}$ is excreted in the faeces and urine because of its high unavailability. Animal waste is then applied to soil, and this allows P to wash into ground water. Supplementation of animal feed with microbial phytase increases P availability. This has been observed in broilers (Cabahug et al., 1999; Sohail \& Roland, 1999; Waldroup et al., 2000; Yan et al., 2001; Ribeiro et al., 2003). Research published on laying hen performance (Gordon \& Roland, 1997; Van der Klis et al., 1997; Carlos \& Edwards, 1998; Gordon \& Roland, 1998; Punna \& Roland, 1999; Um \& Paik, 1999; Boling et al., 2000; Keshavarz, 2000; Jalal \& Scheideler, 2001; Narahari \& Jayaprasad, 2001; Keshavarz, 2003; Lim et al., 2003) has found a beneficial effect of phytase supplementation on feed intake, egg production, egg weights, eggshell quality and $\mathrm{P}$ utilization. Most of these studies were conducted in environmentally controlled houses at a thermo- neutral zone. However, high ambient temperatures are a problem in countries situated in hot climatic regions, and reduced performance of poultry is recorded during hot summer months in countries with temperate climates. Moreover, heat stress has been associated with decreased feed intake, egg production and protein digestibility and has been shown to reduce plasma inorganic phosphate levels in laying hens and broilers (Usayran et al., 2001). Bonnet (1997) also reported that the total mineral retention in poultry was decreased by heat stress. Supplementation of phytase to layer diets is becoming increasingly important during times of high environmental temperatures. However, little research has focused on the value of supplementing phytase to laying hens receiving diets low in dietary $\mathrm{P}$ while exposed to high ambient temperatures (Persia et al., 2003). 
This experiment was conducted to determine the effects of a microbial phytase supplementation on egg production, egg weight, feed conversion, feed consumption and egg quality criteria on laying hens fed two levels of dietary phosphorus during high ambient temperatures in summer months.

\section{Materials and Methods}

Four hundred and eighty 54-week old Nick-Brown hens were assigned to four dietary treatments. The trial was conducted between April and August in the summer season in Turkey in an open-sided naturally ventilated layer house. Each treatment consisted of four replications of 10 cages (three hens per cage). The hens of 10 adjacent cages were considered an experimental replicate. Individual body weights of all hens were taken at the onset and at termination of the experiment to determine their average body weight. The experimental diets were: $4.5 \mathrm{~g}$ available phosphorus (aP)/kg without phytase (control); $4.5 \mathrm{~g}$ aP/ $/ \mathrm{kg}$ with phytase; $3.0 \mathrm{~g} \mathrm{aP} / \mathrm{kg}$ without phytase; $3.0 \mathrm{~g}$ aP/kg with phytase. Commercial microbial phytase, Natuphos ${ }^{\circledR}$, was added at 300 phytase unit (FTU)/kg diet. The diets were isonitrogenous (16.50\% crude protein) and isoenergetic (11.5 MJ, ME/kg).

Table 1 Ingredient and chemical composition of the experimental diets (as fed)

\begin{tabular}{|c|c|c|c|c|}
\hline & \multicolumn{4}{|c|}{ Available phosphorus level in layer feed, g/kg } \\
\hline & 0.045 & 0.045 & 0.030 & 0.030 \\
\hline \multicolumn{5}{|l|}{ Ingredients (g/kg) } \\
\hline Maize & 638.6 & 638.0 & 643.4 & 642.8 \\
\hline Soya bean meal (48 \% CP) & 125.0 & 125.0 & 140.0 & 140.0 \\
\hline Sunflower meal (36 \% CP ) & 100.0 & 100.0 & 100.0 & 100.0 \\
\hline Meat and bone meal & 30.0 & 30.0 & 19.0 & 19.0 \\
\hline Fish meal & 15.3 & 15.3 & 9.0 & 9.0 \\
\hline Limestone & 80.3 & 80.3 & 81.1 & 81.1 \\
\hline Dicalcium phosphate & 3.8 & 3.8 & - & - \\
\hline Salt & 2.5 & 2.5 & 2.5 & 2.5 \\
\hline Mineral premix* & 2.5 & 2.5 & 2.5 & 2.5 \\
\hline Vitamin premix** & 1.0 & 1.0 & 1.0 & 1.0 \\
\hline Phytase (Natuphos $\left.{ }^{\circledR} 500000 \mathrm{FTU} / \mathrm{kg}\right)^{\ddagger}$ & - & 0.6 & - & 0.6 \\
\hline Methionine & 1.0 & 1.0 & 1.5 & 1.5 \\
\hline Total & 1000 & 1000 & 1000 & 1000 \\
\hline \multicolumn{5}{|l|}{ Composition, analysed (g/kg) } \\
\hline Dry matter & 908.5 & 909.1 & 910.2 & 912.5 \\
\hline Crude protein & 165.3 & 163.5 & 162.9 & 163.0 \\
\hline Crude fat & 29.5 & 32.5 & 33.5 & 33.5 \\
\hline Crude fibre & 42.1 & 43.5 & 39.5 & 41.2 \\
\hline Crude ash & 119.5 & 118.9 & 119.0 & 120.9 \\
\hline Calcium & 35.3 & 35.0 & 32.8 & 33.5 \\
\hline Total phosphorus & 6.3 & 6.1 & 5.0 & 5.3 \\
\hline Metabolisable energy ${ }^{\ddagger \ddagger}$ ( MJ/kg) & 11.4 & 11.6 & 11.5 & 11.6 \\
\hline Available phosphorus ${ }^{\ddagger}$ & 4.5 & 4.5 & 3.0 & 3.0 \\
\hline Lysine $\mathrm{f \neq}^{\neq}$ & 8.1 & 8.1 & 8.0 & 8.0 \\
\hline Met+Cys & 6.5 & 6.5 & 6.5 & 6.5 \\
\hline
\end{tabular}

*Mineral premix (mg/kg diet): Mn - 80; Fe - 80; Zn - 60; Cu - 8; Co - 0.2; I - 0.5; Se - 0.15

**Vitamin premix (/kg diet): Vitamin A - $12000 \mathrm{IU}$; vitamin $\mathrm{D}_{3}$ - $2400 \mathrm{IU}$; vitamin E - $30 \mathrm{IU}$; vitamin $\mathrm{K}_{3}$ - $2.5 \mathrm{mg}$; vitamin $\mathrm{B}_{1}$ - $3 \mathrm{mg}$; vitamin $\mathrm{B}_{2}-7 \mathrm{mg}$; niacin - $40 \mathrm{mg}$; calcium D-pantothenate - $8 \mathrm{mg}$; vitamin $\mathrm{B}_{6}$ - $4 \mathrm{mg}$; vitamin $\mathrm{B}_{12}$ $0.015 \mathrm{mg}$; folic acid - $1 \mathrm{mg}$; D-biotine - $0.045 \mathrm{mg}$; vitamin C - $50 \mathrm{mg}$; chorine chloride - $125 \mathrm{mg}$

${ }^{\ddagger}$ One phytase unit FTU/kg unit is defined as the amount that liberates $1 \mu \mathrm{mol}$ of inorganic P/ min from $0.0015 \mathrm{~mol}$ sodium phytate at $37^{\circ} \mathrm{C}$ and $\mathrm{pH} 5.5$

\# Calculated

The hens received the experimental diets for 20 weeks. Diets in mash form and water were provided ad libitum. A photoperiod of 17 hours/day was given. Egg productions and broken/cracked eggs were recorded daily during 54 to 74 weeks of age. Random samples of 60 eggs for two consecutive days from each treatment were weighed individually to determine average egg weight. Random samples of 30 eggs from each treatment were collected every four weeks to measure egg quality such as eggshell thickness, 
eggshell strength and eggshell weight. Mortality was recorded daily. Production parameters such as feed intake and egg production were adjusted for hen mortalities. Standard techniques of the proximate analyses were used to determine the nutrient concentrations in the diets (Naumann \& Bassler, 1993). The experimental diets were also analysed for starch, sugar, total calcium and phosphorus, according to the VDLUFA method (Naumann \& Bassler, 1993). Metabolisable energy content of the diets was calculated based on chemical composition (Anon., 1991). Data were analysed using the general linear models procedure of SAS (1985). Significant treatment effects were detected by Duncan's multiple range test. Differences were considered significant at $\mathrm{P}<0.05$. Results were expressed as means with their standard errors.

\section{Results and Discussion}

The effect of dietary supplementation of phytase on the egg production, feed consumption, feed conversion, proportion of cracked/broken eggs, body weight and body weight gain of hens is presented in Table 2.

Table 2 The effect of phytase supplementation to the diets of hens on egg production, feed consumption, feed conversion ratio, incidence of cracked/broken egg and body weight

\begin{tabular}{lcccccc}
\hline Parameters & $\begin{array}{c}4.5 \mathrm{~g} \mathrm{aP} / \mathrm{kg} \\
\text { without } \\
\text { phytase }\end{array}$ & $\begin{array}{c}4.5 \mathrm{~g} \mathrm{aP} / \mathrm{kg} \\
\text { with } \\
\text { phytase }\end{array}$ & $\begin{array}{c}3.0 \mathrm{~g} \mathrm{aP} / \mathrm{kg} \\
\text { without } \\
\text { phytase }\end{array}$ & $\begin{array}{c}3.0 \mathrm{~g} \mathrm{aP} / \mathrm{kg} \\
\text { with } \\
\text { phytase }\end{array}$ & $\begin{array}{c}\text { Pooled } \\
\text { s.e. }\end{array}$ & P \\
\hline Egg production, hen-d, \% & $75.49^{\mathrm{c}}$ & $77.96^{\mathrm{a}}$ & $64.59^{\mathrm{d}}$ & $76.54^{\mathrm{b}}$ & 0.39 & 0.0001 \\
Feed consumption, g/hen/d, & $101.31^{\mathrm{b}}$ & $103.43^{\mathrm{a}}$ & $95.24^{\mathrm{c}}$ & $101.69^{\mathrm{b}}$ & 0.58 & 0.0001 \\
Feed conversion, & $2.13^{\mathrm{b}}$ & $2.06^{\mathrm{b}}$ & $2.38^{\mathrm{a}}$ & $2.08^{\mathrm{b}}$ & 0.38 & 0.0001 \\
feed, g/eggs, g & 2.30 & 2.41 & 2.35 & 2.43 & 0.15 & 0.9272 \\
Cracked/broken eggs, \% & 1927 & 1960 & 1921 & 1917 & 15.27 & 0.8889 \\
Body weight, g (54 wk of age) & $1898^{\mathrm{bc}}$ & $1965^{\mathrm{a}}$ & $1858^{\mathrm{c}}$ & $1923^{\mathrm{ab}}$ & 16.35 & 0.0002 \\
\hline Body weight, g (74 wk of age $)$ & & & & & & \\
\hline
\end{tabular}

aP - available phosphorus

a-d: Means within rows with different superscripts differ at $\mathrm{P}<0.05$

A significant $(\mathrm{P}<0.05)$ phytase by phosphorus interaction in egg production was observed throughout the experiment. Phytase supplementation to the control diet, $4.5 \mathrm{~g} \mathrm{aP} / \mathrm{kg}$, and the low $3.0 \mathrm{~g} \mathrm{aP} / \mathrm{kg}$ diet increased $(\mathrm{P}<0.0001)$ hen-day egg production from 75.49 to $77.96 \%$ and from 64.59 to $76.54 \%$, respectively. Hen-day egg production of hens consuming $3.0 \mathrm{~g} \mathrm{aP} / \mathrm{kg}$ diet with phytase was also higher than that of the control diet. Low $3.0 \mathrm{~g}$ aP/kg diet without phytase demonstrated a depression in egg production and was lower than all other dietary treatments. However, phytase supplementation to the $3.0 \mathrm{~g} \mathrm{aP} / \mathrm{kg}$ diet completely corrected this adverse effect. This result is in agreement with observations by Van der Klis et al. (1997), Um \& Paik (1999) and Keshavarz (2000) who observed that phytase supplementation to the diet containing between 3.0 and $3.5 \mathrm{~g} \mathrm{aP} / \mathrm{kg}$ increased hen-day egg production significantly. Average daily feed consumption was significantly different between treatments. Phytase supplementation to the control (4.5 g $\mathrm{aP} / \mathrm{kg})$ and to the low $\mathrm{P}$ diet $(3.0 \mathrm{~g} \mathrm{aP} / \mathrm{kg})$ increased $(\mathrm{P}<0.0001)$ daily feed consumption from 101.31 to $103.43 \mathrm{~g}$ and from 95.24 to $101.69 \mathrm{~g}$, respectively. This finding is in agreement with that of Um \& Paik (1999) who reported that phytase supplementation to the control diet containing $3.7 \mathrm{~g} \mathrm{aP} / \mathrm{kg}$ increased feed consumption significantly from $112.4 \mathrm{~g}$ to $114.8 \mathrm{~g}$. Van der Klis et al. (1997) and Gordon \& Roland (1998) also observed that phytase supplementation to the diets containing about $3.4 \mathrm{~g}$ aP/kg increased feed consumption significantly. However, Punna \& Roland (1999) reported that phytase supplementation to the diets containing $3.0 \mathrm{~g} \mathrm{aP} / \mathrm{kg}$ significantly decreased feed consumption from 85.7 to $79.8 \mathrm{~g}$. The feed conversion ratio of the $3.0 \mathrm{~g} \mathrm{aP} / \mathrm{kg}$ without phytase treatment was significantly higher in the other treatments. Phytase supplementation to the $3.0 \mathrm{~g}$ aP/ $/ \mathrm{kg}$ diet improved $(\mathrm{P}<0.05)$ feed conversion ratio. Jalal \& Scheideler (2001) also reported that phytase supplementation containing 3.5 g non phytate P/kg significantly improved the feed conversion ratio of laying hens. On the other hand, Van der Klis et al. (1997) and Um \& Paik (1999) observed that phytase supplementation to the diets containing 3.3 and $3.7 \mathrm{~g} \mathrm{aP} / \mathrm{kg}$ had no beneficial effect on feed conversion ratio. There were no differences between treatments on number of cracked/broken eggs. Body weight was not different between treatments at the start of the experiment (54 wk of age), but at the end of the experiment (74 wk of age), the effect of phytase on body weight was significant, with $4.5 \mathrm{~g} \mathrm{aP} / \mathrm{kg}$ with phytase being the highest and $3.0 \mathrm{~g} \mathrm{aP} / \mathrm{kg}$ without phytase the lowest. Body weight 
gain of the $3.0 \mathrm{~g} \mathrm{aP} / \mathrm{kg}$ with phytase diet was higher than the diet containing $3.0 \mathrm{~g} \mathrm{aP} / \mathrm{kg}$ without phytase. Body weight increases have been reported after phytase supplementation (Gordon \& Roland, 1997; Van der Klis et al., 1997; Carlos \& Edwards, 1998; Gordon \& Roland, 1998; Keshavarz, 2000).

The effect of phytase supplementation to the diet on egg weight and egg quality criteria is shown in Table 3. Phytase supplementation to the control $(4.5 \mathrm{~g} \mathrm{aP} / \mathrm{kg})$ and the $3.0 \mathrm{~g}$ aP $/ \mathrm{kg}$ diet increased $(\mathrm{P}<0.05)$ egg weight from 62.66 to $64.32 \mathrm{~g}$ and from 62.49 to $63.98 \mathrm{~g}$, respectively. These results are consistent with other reports that phytase had a favourable effect on egg weight (Van der Klis et al., 1997; Um \& Paik, 1999; Keshavarz, 2000). There were no significant differences between treatments in eggshell weight, eggshell thickness, eggshell strength and proportion of cracked/broken eggs. Average mortality observed in the hens fed diets $4.5 \mathrm{~g}$ aP/ $\mathrm{kg}$ without phytase, $4.5 \mathrm{~g}$ aP/ $/ \mathrm{kg}$ with phytase, $3.0 \mathrm{~g}$ aP/ $/ \mathrm{kg}$ without phytase and $3.0 \mathrm{~g} \mathrm{aP} / \mathrm{kg}$ with phytase were $3.33,2.50,8.33$ and $1.67 \%$, respectively.

Table 3 The effect of phytase supplementation to the diet on egg weight (g) and egg quality criteria (mean \pm s.e.)

\begin{tabular}{lcccccc}
\hline \multirow{2}{*}{ Parameters } & $\begin{array}{c}4.5 \mathrm{~g} \mathrm{aP} / \mathrm{kg} \\
\text { without } \\
\text { phytase }\end{array}$ & $\begin{array}{c}4.5 \mathrm{~g} \mathrm{aP} / \mathrm{kg} \\
\text { with } \\
\text { phytase }\end{array}$ & $\begin{array}{c}3.0 \mathrm{~g} \mathrm{aP} / \mathrm{kg} \\
\text { without } \\
\text { phytase }\end{array}$ & $\begin{array}{c}3.0 \mathrm{~g} \mathrm{aP} / \mathrm{kg} \\
\text { with } \\
\text { phytase }\end{array}$ & $\begin{array}{c}\text { Pooled } \\
\text { s.e. }\end{array}$ & P \\
\hline Egg weight, g & $62.66^{\mathrm{b}}$ & $64.32^{\mathrm{a}}$ & 62.49 & $63.9 \mathrm{a}^{\mathrm{a}}$ & 0.15 & 0.0001 \\
Eggshell weight, g & 6.03 & 6.07 & 6.22 & 6.14 & 0.07 & 0.2528 \\
Eggshell strength, kg/cm & 2.80 & 2.91 & 2.81 & 2.86 & 0.11 & 0.8881 \\
Cracked-broken egg, \% & 2.30 & 2.41 & 2.35 & 2.43 & 0.15 & 0.9272 \\
Egg yolk weight, g & 16.50 & 16.19 & 16.69 & 16.63 & 0.19 & 0.2553 \\
Eggshell thickness, mm & 0.379 & 0.383 & 0.389 & 0.382 & 0.01 & 0.2257 \\
\hline
\end{tabular}

aP - available phosphorus

${ }^{\mathrm{a}-\mathrm{b}:}$ Means within rows with different superscripts differ at $\mathrm{P}<0.05$

The mortality of hens fed the diet containing $3.0 \mathrm{~g} \mathrm{aP} / \mathrm{kg}$ without phytase increased slightly (8.33\%) compared to the other diets. Mortality increased slightly and body weight losses were recorded in hens fed the diet containing $3.0 \mathrm{~g} \mathrm{aP} / \mathrm{kg}$ without phytase. This was attributed to the high temperatures (Table 4) in the open-sided layer house where the experiment was conducted.

Table 4 Means house temperatures $\left({ }^{\circ} \mathrm{C}\right)$ during the study

\begin{tabular}{lllll}
\hline \multirow{2}{*}{ Months of the experiment } & \multicolumn{3}{c}{ Time of day } \\
\cline { 2 - 5 } A:00 & $13: 30$ & $16: 00$ & Means \\
May & 16.9 & 20.6 & 20.8 & 19.43 \\
June & 26.9 & 34.5 & 35.8 & 32.40 \\
July & 28.3 & 35.7 & 36.8 & 33.60 \\
August & 29.9 & 37.4 & 38.2 & 35.17 \\
\hline
\end{tabular}

\section{Conclusion}

The beneficial effects of phytase supplementation to the laying hen diets were clearly evident from this study during a period of high ambient temperature. Hens consuming the $3.0 \mathrm{~g}$ aP/ $\mathrm{kg}$ diet with phytase performed as well as hens fed the diet containing $4.5 \mathrm{~g}$ aP/kg without phytase. Phytase supplementation during high ambient temperature can also lower the cost of the diet by reducing the amount of inorganic $\mathrm{P}$ added to a diet.

\section{Acknowledgements}

Financial and technical assistance of the Poultry Research Institute of Erbeyli, Aydın is gratefully acknowledged. 


\section{References}

Anonymous, 1991. Animal feeds - Determination of metabolizable energy (chemical method). Turkish Standards Institute (TSE), Publ. No. 960, 1-3.

Boling, S.D., Douglas, W.M., Johnson, M.L., Wang, X., Parsons, C.M., Koelkebeck, K.W. \& Zimmerman, R.A., 2000. The effects of dietary available phosphorus levels and phytase on performance of young and older laying hens. Poult. Sci. 79, 224-230.

Bonnet, S., Geraert, P.A., Lessire, M., Carre, B. \& Solange Guillaumin, 1997. Effect of high ambient temperature on feed digestibility in broilers. Poult. Sci. 76, 857-863.

Cabahug, S., Ravindran, V., Selle, P.H. \& Bryden, W.L., 1999. Response of broiler chickens to microbial phytase supplementation as influenced by dietary phytic acid and nonphytate phosphorus contents. I. Effects on bird performance and toe ash. Br. Poult. Sci. 40, 660-666.

Carlos, A.B. \& Edwards, H.M., 1998. The effect of 1.25-dihydroxycholicalciferol and phytase on the natural phytate phosphorus utilization by laying hens. Poult. Sci. 77, 850-858.

Gordon, R.W. \& Roland, S.R., 1997. Performance of commercial laying hens fed various phosphorus levels, with and without supplemental phytase. Poult. Sci. 76, 1172-1177.

Gordon, R.W. \& Roland, S.R., 1998. Influence of supplemental on calcium and phosphorus utilization in laying hens. Poult. Sci. 77, 290-294.

Jalal, M.A. \& Scheideler, S.E., 2001. Effect of supplementation of two different sources of phytase on egg production parameters in laying hens and nutrient digestibility. Poult. Sci. 80, 1463-1471.

Keshavarz, K., 2000. Nonphytate phosphorus requirement of laying hens with and without phytase on a phase feeding program. Poult. Sci. 79, 748-763.

Keshavarz, K., 2003. The effect of different levels of nonphytate phosphorus with and without phytase on performance of for strains of laying hens. Poult. Sci. 83, 71-91.

Lim, H.S. Namkung, H. \& Paik, I.K., 2003. Effects of phytase supplementation on the performance, egg quality and phosphorus excretion of laying hens fed different levels of dietary calcium and nonphytate phosphorus. Poult. Sci. 82, 92-99.

Narahari, D. \& Jayaprasad, A., 2001. Effect of replacement of non-phytate phosphorus and phytase supplementation on layers’ performance. Ind. J. Anim. Sci. 71, 491-492.

Naumann, C. \& Bassler, R., 1993. Die chemische untersuchung von futtermitteln. methodenbuch, band III. 3. Erg.,VDLUFA-Verlag, Darmstadt.

Persia, M.E., Utterback, P.L., Biggs, P.E., Koelkebec, K.W. \& Parsons, C.M., 2003. Interrelationship between environmental temperature and dietary nonphytate phosphorus in laying hens. Poult. Sci. 82, 1763-1768.

Punna, S. \& Roland, S.R., 1999. Influence of supplemental microbial phytase on first cycle laying hens fed phosphorus-deficient diets from day one of age. Poult. Sci. 78, 1407-1411.

Riberio, A.M.L., Mireles, A.J. \& Klasing, K.C., 2003. Interactions between dietary phosphorus level, phytase supplementation and pelleting on performance and bone parameters of broilers fed high levels of rice bran. Anim. Feed Sci. Technol. 103, 155-161.

SAS, 1985. Statistical Analysis Systems user’s guide (5th ed.). SAS Institute Inc., Cary, North Carolina, USA.

Sohail, S.S. \& Roland, D.A., 1999. Influence of supplemental phytase on performance of broiler four to six weeks of age. Poult. Sci. 76, 1535-1542.

Um, S.J. \& Paik, K.I., 1999. Effect of microbial phytase supplementation on egg production, eggshell quality and mineral retention of laying hens fed different level of phosphorus. Poult. Sci. 78, 75-79.

Usayran, N., Farran, M.T., Awadallah, H.H.O., Al-Hawi, I.R., Asmar, R.J. \& Ashkarian, V.M., 2001. Effects of added dietary fat and phosphorus on the performance and egg quality of laying hens subjected to a constant high environmental temperature. Poult. Sci. 80, 1695-1701.

Van der Klis, J.D., Versteegh, H.A.J., Simons, P.C.M. \& Kies, A.K., 1997. The efficacy of phytase in cornsoybean meal-based diets for laying hens. Poult. Sci. 76, 1535-1542.

Waldroup, P.W., Kersey, J.H., Saleh, E.A., Fritts, C.A., Stilborn, H.L., Crum, R.C. \& Raboy, V., 2000. Nonphytate phosphorus requirement and phosphorus excretion of broiler chicks fed diets composed of normal or high available phosphate corn with and without microbial phytase. Poult. Sci. 79, 1451-459.

Yan, F., Kersey, J.H. \& Waldroup, P.W., 2001. Phosphorus requirements of broiler chicks three to six weeks of age as influenced by phytase supplementation. Poult. Sci. 80, 445-449.

The South African Journal of Animal Science is available online at http://www.sasas.co.za/Sajas.html 